\title{
CIITA wt Allele
}

National Cancer Institute

\section{Source}

National Cancer Institute. CIITA wt Allele. NCI Thesaurus. Code C96014.

Human CIITA wild-type allele is located in the vicinity of $16 \mathrm{p} 13$ and is approximately $48 \mathrm{~kb}$ in length. This allele, which encodes MHC class II transactivator protein, is involved in the modulation of MHC class II gene expression. 